\title{
ARTICLE
}

\section{A comparative study of the seedling production technology of Picea obovata L. in the forest-steppe ecotone of northern Mongolia}

\author{
Jagdag Damdinjamts ${ }^{1}$, Batsaikhan Ganbaatar ${ }^{3}$, Baatarbileg Nachin ${ }^{1}$, Naranbayar Erdenechuluun ${ }^{3}$ \\ Ganbat Dashzeveg ${ }^{3}$, Bayartulga Altanhuyag ${ }^{3}$ and Gerelbaatar Sukhbaatar ${ }^{1,2 *}$ \\ ${ }^{1}$ Institute of Forest Science, National University of Mongolia, Ulaanbaatar, Mongolia \\ ${ }^{2}$ Department of Environment and Forest Engineering, School of Engineering and Applied Sciences, \\ National University of Mongolia, Ulaanbaatar, Mongolia \\ ${ }^{3}$ Division of Forest Resources and Forest Protection, Institute of Geography and \\ Geoecology, Mongolian Academy of Sciences, Ulaanbaatar, Mongolia
}

ARTICLE INFO: Received: 22 Apr, 2021; Accepted: 21 Sep, 2021

Abstract: The success of reforestation largely depends on the quality of the seedling. This study focuses on comparative assessments of the experimental planting of Picea obovata seedlings under various growing conditions, including in a greenhouse and open field. The objectives were to carry out a comparative study of the effect of different care regimes on the growth of seedling, and to choose the most optimal treatment that accelerates the growth of seedlings on the basis of the results taken from the comparative analysis. The study was carried out in the Experimental Forest Nursery of the Institute of Geography and Geoecology, MAS in the period between 2018 and 2020. The experimental planting design included four treatments with varying irrigation norms, air temperatures, air relative humidity, shading rates. Two of these experiments were put in greenhouses, and the remaining two treatments were in the open field. Repeated measurements and sampling were performed at the end of each growing season. The results showed high variation in seedling height $(p<0.0001 ; F=38.6)$ and diameter $(p<0.0001 ; F=43.2)$ growth and biomass accumulation $(p<0.0001)$. These variables therefore, positively corresponded to the air temperature, air relative humidity and moisture sufficiency in the soils. We found that the seedlings had faster growth in height (52.4\%) and diameter (62.3\%), and there was more biomass accumulation (128.1\%) under greenhouse conditions than outdoors. With regard to the biomass allocation, a three-year observation showed a greater proportion of stem biomass in the total biomass, and, conversely, the predominant proportion of needle biomass accounted for open field treatments. However, the creation of stable condition in the greenhouse with a high relative humidity (more than 75\%; daily watering norm of 20 liters per day) and an internal temperature of $25^{\circ} \mathrm{C}(40 \%$ shading) had the most positive effect on the growth and accumulation of biomass of seedlings. Consequently, we conclude that to meet the existing needs for seedlings for the restoration of natural Picea obovata forests, seedling production in greenhouses should be recommended.

Keywords: Picea obovata; seedling; growth; diameter; height; biomass;

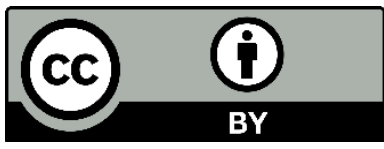

The Author(s). 2021 Open access This article is distributed under the terms of the Creative Commons Attribution 4.0 International License (https://creativecommons.org/licenses/by/4.0/), which permits unrestricted use, distribution, and reproduction in any medium, provided you give appropriate credit to the original author(s) and the source, provide a link to the Creative Commons license, and indicate if changes were made. 


\section{INTRODUCTION}

Siberian spruce is the main forestforming and evergreen tree species, widespread in the northern hemisphere, covering the territory of Finland, Russia and Mongolia. The main part of the natural distribution of Siberian spruce forests belongs to Central and Eastern Siberia, and the Far East of Russia. Spruce forests in Mongolia play an important ecological role in the sustainability of forest ecosystems and are distributed in the northern part of the country, coinciding with the distribution of permafrost. They mainly grow on the north-facing slopes, lower edges of mountains, and along the valleys of small rivers, forming mixed forests.

According to statistics [1], a total of 21.1 thousand hectares of Siberian spruce forests were registered at the country level, which occupy only 0.18 per cent of forest cover of Mongolia. Such a limited area and biological resources of Siberian spruce in the country demonstrate the importance of silvicultural treatments to ensure successful natural regeneration and restoration of degraded and deforested natural spruce forests with highquality seedlings grown in forest nurseries of the country. In Mongolia, several studies have been done to develop seedling production technology for Larix sibirica Ledeb and Pinus sylvestris L. seedlings in the greenhouses [2-5], open fields [6,7] and in different boreal forest

\section{MATERIALS AND METHODS}

\section{Study area and treatments}

The study was carried out in the Experimental forest nursery in Dambadarjaa ( $47^{\circ} 59^{\prime} \mathrm{N}$ and $106^{\circ} 57^{\prime} \mathrm{E}$ ) located in the Green zone of Ulaanbaatar city. Geographically, the study area is considered as the southwestern end of the Khentii Mountain [23] Ranges. The climate in the study area is cold, semi-arid and regions [8-10] of northern Mongolia. Therefore, in the semi-arid and arid regions of the country, similar studies have been done on Haloxylon ammodendron [11], Elaeagnus Moorcroftii [12], and Populus diversifolia [13]. In relation to forest degradation and deforestation in Mongolia, caused by global warming and unsustainable forest management, there is an urgent need to restore natural Siberian spruce forests.

A number of studies have emphasized that the success of restoration depends not only on the site quality [14-15] and post-planting stress of transplanted seedlings [16-19], but also on the quality of seedlings [20-22] that are used for restoration. In addition, several studies noted that seedling production in greenhouses is one of potential tools to meet the existing reforestation needs using high-quality seedlings. In spite of the importance of Siberian spruce forests in Mongolia, there is very little information on the development of seedling production technology of Picea obovata.

The aim of this study was 1) to carry out a comparative study of the effect of different care regimes on the growth of seedling, and 2) based on the results of a comparative analysis, to select the most optimal method that accelerates the growth of seedlings that can be used for seedling production of Picea obovata in Mongolia.

harsh continental with a precipitation peak between June and August. The dry season extends from March to June in spring and from September to October in autumn. The mean temperature is $0.8^{\circ} \mathrm{C}$ and annual precipitation averages $276.4 \mathrm{~mm}$.

The soils in the area are mainly Umbrisols, Chernozems and Kastanozems [24]. 
Table 1. Chemical and textural properties of soils of different treatments

\begin{tabular}{lccccccc}
\hline \multicolumn{1}{c}{ Treatment ID } & $\mathrm{pH}$ & $\begin{array}{c}\text { Humus } \\
(\%)\end{array}$ & $\mathrm{EC}$ & \multicolumn{2}{c}{ Available, $\mathrm{mg}^{100 \mathrm{~g}^{-1} /}$} & Rocks & Soil texture \\
\hline Greenhouse - 1 (GH-1) & 7.2 & 5.175 & 0.336 & 4.01 & 34.5 & 14.33 & loamy soil \\
Greenhouse - 2(GH-2) & 6.6 & 4.399 & 0.042 & 3.97 & 45.6 & 23.26 & loamy soil \\
Open field -1 (OF-1) & 7.5 & 6.319 & 0.427 & 6.61 & 36.7 & 22.63 & loamy soil \\
Open field -2 (OF-2) & 7.1 & 5.094 & 0.149 & 3.16 & 25. & 14.29 & loamy soil \\
\hline
\end{tabular}

From an agrochemical point of view, the soils used for this study are rather nutritious and light loamy, the chemical acidity of the soils is weak, close to neutral (Table 1). The soil preparation in both greenhouse and open field was carried out before seed sowing in accordance with the developed method of Dashzeveg and Amartuvshin (2012) [7]. The experimental planting treatments included seed sowing inside the greenhouse and in the open field, which were equipped with irrigation systems.

High-quality seeds of Picea obovata (germination rate $-86 \%$; weight of 1000 seeds - 5.5 g; germination energy - 77\% (standard MNS 2430: 2009) were used for experimental planting on May 15, 2018. The seeds were sown on prepared soil to a depth of $0.6 \mathrm{~cm}$ and covered with a thin layer of sawdust. Therefore, the daily watering norm (WN) in greenhouses were set at 20 and 30 liters per $\mathrm{m}^{2}$, and in open field - 20 and 30 liters per $\mathrm{m}^{2}$, respectively.

Air temperature (AT), air relative humidity (ARH) and shading rate (SR) differed in the treatments. Inside the greenhouse, we created two different conditions, namely GH-1 (AT: $25-28^{\circ} \mathrm{C}$; RAH: $>80 \%$; SR: 40\%; WN: 20 1 day $^{-1}$ ) and GH-2 (AT: 20-23; RAH: 70-75\%; without shading; WN: 301 day $^{-1}$ ), and in the open field OF-1 (WN: 201 day $^{-1}$; SH: 40\%) and OF-2 (WN: 301 day $^{-1}$; without shading), respectively. Each experimental treatment had 5 replications.

The shading material was used to keep soil moisture, and to reduce the influence of direct sunlight. For 3 years of observations from 2018 to 2020, we carried out the following maintenance measures, including watering, weeding, loosening the soil and covering with sawdust for wintering according to the method developed by Ch. Bazarsad $(1988,1989)$ and C. Dashzeveg (2014) [25,5].

\section{Measurements and data collection}

Repeated measurements and collection of sample materials of seedling that were growing in different treatment conditions were performed at the end of each growing season in September 2018, 2019 and 2020. From each treatment, 100 seedlings were selected for measurement using a fully randomized sampling, and 40 biomass samples (with 3 replicates) were taken annually for biomass analysis. Stem height, root length, stem and root diameter were measured with digital calipers (Traceable Digital Stainless-Steel Caliper, 150 $\mathrm{mm}$ ) and measuring type (Powerlock ${ }^{\circledR}$ tape measure). An ORIA Indoor Hydrometer Thermometer was installed to measure air relative humidity and air temperature in greenhouses. Biomass samples were washed with water to remove soil particles, and dried in the laboratory at $80^{\circ} \mathrm{C}$ for 48 hours. The total biomass was estimated as the sum of the components of the biomass, including the biomass of the stem, root, and needles. Soil samples were taken from the topsoil of each treatment and were analyzed at the "Laboratory of Soil Science", Institute of Geography and Geoecology, MAS.

\section{Statistical analyses}

One-way ANOVA was used to determine whether there were any statistically significant differences between the means of two or more independent groups, and XLSTAT was used to generate a subsample of observations from a set of univariate or multivariate data.

Therefore, to reflect a linear correlation of independent variables we used a Pearson's correlation method. We also used Duncan's Multiple Range test (DMRT) to measure specific differences between pairs of means and to select the most optimum planting treatment. 


\section{RESULTS AND DISCUSSION}

\section{Seedling growth responses to different treatments}

The statistical differences between the four treatments among the main variables for Picea obovata seedlings are shown in Table 1.

Table 2. Statistical differences between treatments among the main variables

\begin{tabular}{clcccc}
\hline No & \multicolumn{1}{c}{ Variables } & df & F Value & $\operatorname{Pr}>\mathrm{F}$ & $\mathrm{R}^{2}$ \\
\hline 1 & Diameter, $\mathrm{mm}$ & 3 & $43.249^{* * *}$ & $<.0001$ & 0.282 \\
2 & Height, $\mathrm{m}$ & 3 & $28.593^{* * *}$ & $<.0001$ & 0.635 \\
3 & Needle length, $\mathrm{cm}$ & 3 & $1.252 \mathrm{nc}$ & 0.292 & 0.282 \\
\hline
\end{tabular}

ns- not significant, ${ }^{* * *}$ - significantly different at 0.001

Results of the study indicated that there exist significant differences in diameter $(p<0001)$ and height $(p<0001)$, and insignificant difference in needle length

$(p=0.292)$ due to the different growing conditions that were considered for this study (Table 1).
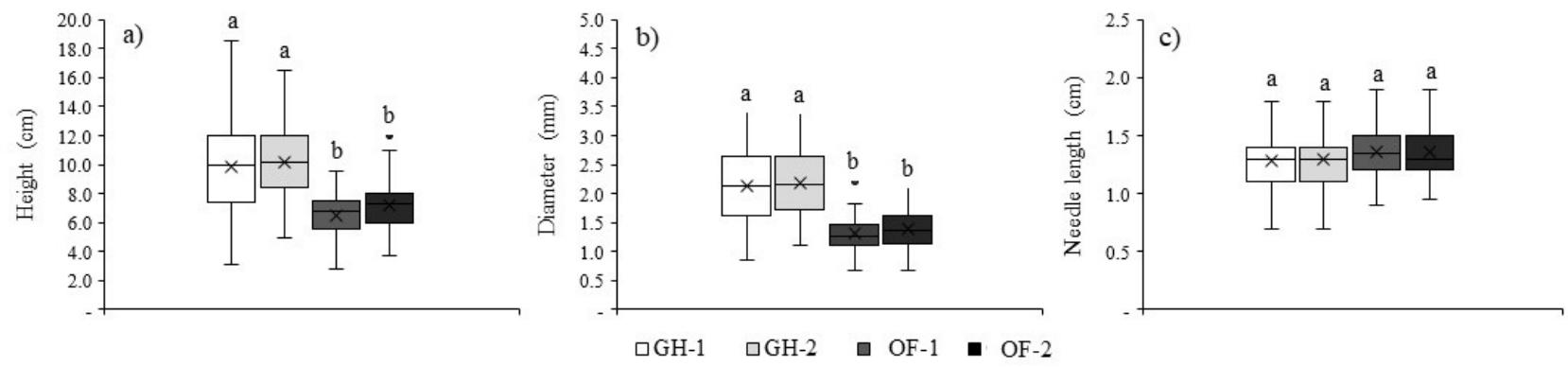

Figure 1. Comparison of the morphological characteristics of seedlings (3-years old) growing in different treatments a) diameter, b) height; c) needle length
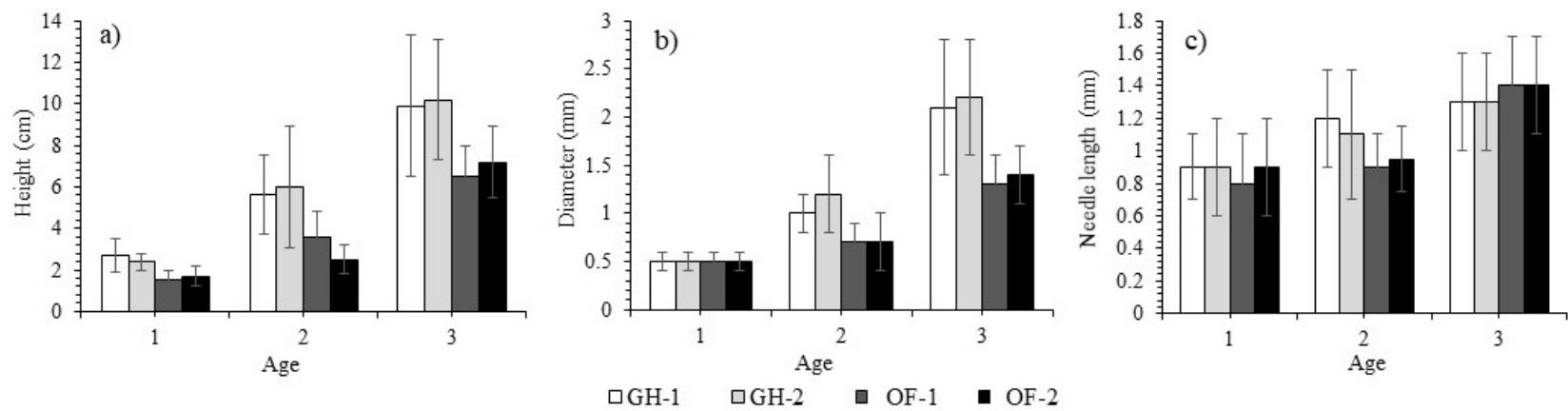

Figure 2. Cumulative growth during the monitoring period (3 years). a) in height, b) in diameter, c) needle length

In comparison, the DMRT showed that at the end of the observation period, the total height and diameter of seedlings growing inside greenhouses (GH-1, GH-2) were often greater than those seen in open field treatments (OF-1, OF-2) (Fig. 1, 2). We found a rising difference in the cumulative growth performence between the greenhouse and open field with seedling age (Fig. 2). The faster growth observed in greenhouses may have been the result of the creation of more optimal growing conditions compared to outdoor environment.

Regarding the differentiation in seedling growth, measurements from the first year showed a very little difference only in height growth, where diameter growth remained at the same level as in the open field. However, from the second year of experimental planting, a noticeable difference was observed in both height and in diameter growth (Fig. 2 a, b). 
The creation of the stable condition with high air relative humidity over (ARH: $80 \%$; WN: 201 day $^{-1}$ ), and inside temperature (AT: $25^{\circ} \mathrm{C}$; SR: $40 \%$ ) in the greenhouse showed most positive effect on the growth and biomass accumulation of seedlings.

\section{Effect of growing condition on biomass accumulation}

In terms of biomass accumulation, quite a slow biomass accumulation rate was observed during the first two years of observation period, which was less than $0.05 \mathrm{~g}$ and $0.1 \mathrm{~g}$ in $1-$ and 2-year-old seedlings, respectively (Fig. 3). Therefore, a noticeable biomass accumulation was observed in 3-year-old seedlings. In particular, the seedlings grown indoor in the greenhouses had much higher biomass than
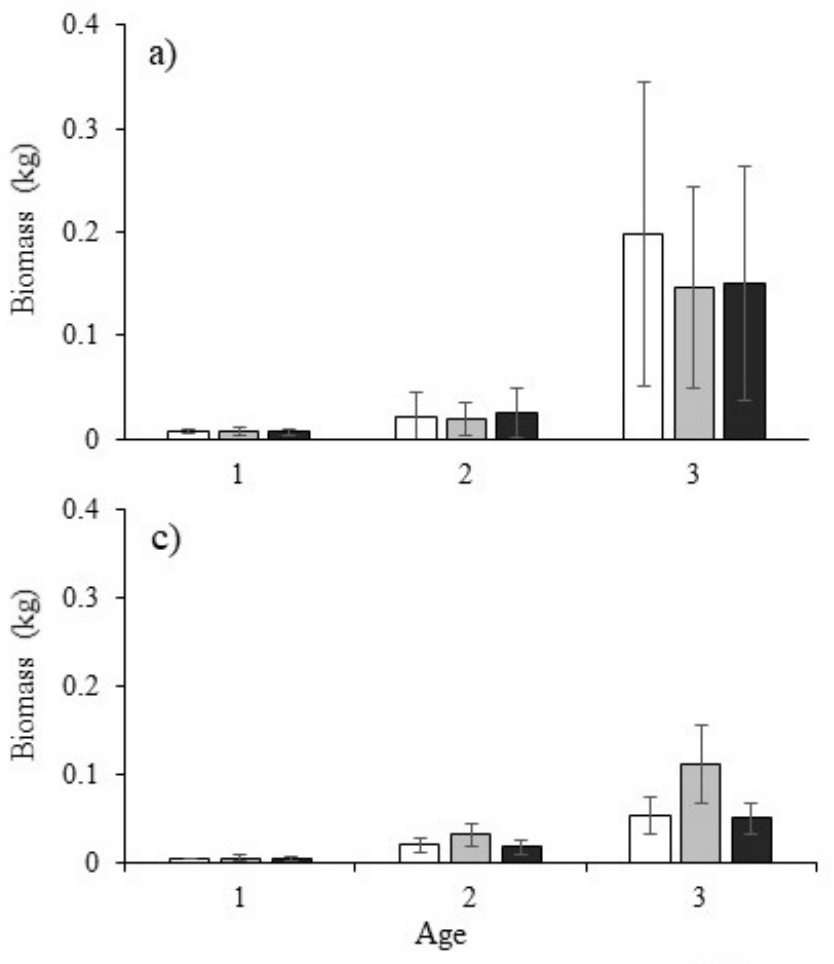

$\square$ Stem seedlings grown in the open field (OF-1 and OF-2).

We found a special pattern of biomass allocation (stem, root, needle) with seedling age. Looking at the biomass allocation graph (Fig. 3), we can see that the allocation of spruce seedling biomass strongly depends on the growing conditions. In comparison, for seedlings growing indoor in the greenhouses, the greatest biomass belonged only to the stem $(0.2 \mathrm{~g})$, contrary to the seedlings growing in the open field, the greatest biomass allocated only to the needle $(0.13 \mathrm{~g})$ (Fig. 3). Here we may conclude that the creation of optimum growing condition inside greenhouses (ARH $(>70 \%)$; AT $\left.\left(20-25^{\circ} \mathrm{C}\right)\right)$ positively effects not only on all biomass components, but also supports faster stem growth and formation for seedlings.
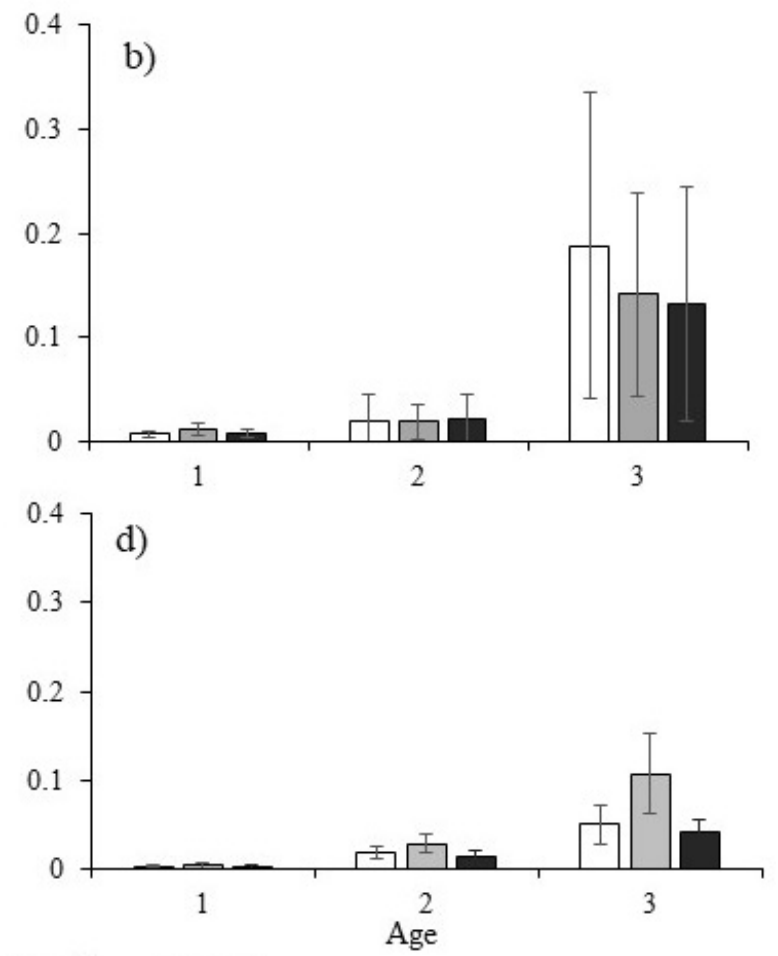

$\square$ Needl $\square$ Root

Figure 3. Changes in biomass allocation over the observation period (in different treatments) The biomass was presented as the total weight of 1000 seedlings for each treatment. a) $\mathrm{GH}-1$; b) $\mathrm{GH}-2$; c) $\mathrm{OF}-1$; d) $\mathrm{OF}-2$;

However, in order to survive and adapt to the severe environmental conditions of northern Mongolia, caused by high fluctuation in air temperature, solar radiation, frequent droughts and less precipitation, the main part of seedling biomass is intended for photosynthetic organ/needle (40-50\%) (Fig. 3 c, d).
In comparison, variables for root systems including the taproot length $(\mathrm{F}=43.249$, $\mathrm{P}<0.0001)$, lateral root length $(\mathrm{F}=28.593$, $\mathrm{P}<0.0001)$ and number of roots $(\mathrm{F}=28.593$, $\mathrm{P}<0.0001) \quad$ statistically differed among treatments. 
On the overall, the root development of seedlings was often better in green-houses. Here, the length of the tap and lateral roots, as well as the root number for the seedlings growing inside greenhouses were greater than in the open field treatments with $0.5 \mathrm{~cm}, 3.3 \mathrm{~cm}$, and 2.3, respectively (Fig 3) Meanwhile, we found that seedlings had a faster growth in height $(52.4 \%)$ and diameter $(62.3 \%)$, and a greater biomass accumulation $(128.1 \%)$ in the greenhouse conditions than in the open field.

\section{Relationship between morphological variables for spruce seedlings}

The morphological parameters of seedlings are the main indicators for describing the quantitative and qualitative properties. In this study, we used a number of morphological variables to determine how seedling growth differs across different growing conditions. We considered morphological variables of aboveground (height, diameter, crown height, crown width) and belowground (length of tapand lateral root, total root number) parts of the seedlings (Table 3 ).

Table 3. Pearson's correlation between above- and below-ground morphological variables for 3-year-old seedlings of Picea obovate

\begin{tabular}{lccccccc}
\hline \multicolumn{1}{c}{ Variables } & $\mathrm{H}(\mathrm{cm})$ & $\mathrm{D}(\mathrm{mm})$ & $\begin{array}{c}\mathrm{L}_{\text {taproot }} \\
(\mathrm{cm})\end{array}$ & $\begin{array}{c}\mathrm{L}_{\text {lateral root }} \\
(\mathrm{cm})\end{array}$ & $\begin{array}{c}\mathrm{RN} \\
(\mathrm{pcs})\end{array}$ & $\begin{array}{c}\mathrm{H}_{\text {crown }} \\
(\mathrm{mm})\end{array}$ & $\begin{array}{c}\text { Width }_{\text {crown }} \\
(\mathrm{cm})\end{array}$ \\
\hline $\mathrm{H}(\mathrm{cm})$ & 1 & & & & & & \\
$\mathrm{D}(\mathrm{mm})$ & $0.850^{*}$ & 1 & & & & & \\
$\mathrm{~L}_{\text {taproot }}(\mathrm{cm})$ & 0.636 & 0.488 & 1 & & & & \\
$\mathrm{~L}_{\text {lateral root }}(\mathrm{cm})$ & 0.537 & 0.563 & 0.412 & 1 & & & \\
$\mathrm{RN}(\mathrm{pcs})$ & -0.098 & -0.035 & -0.087 & -0.185 & 1 & & \\
$\mathrm{H}_{\text {crown }}(\mathrm{mm})$ & $0.988^{*}$ & $0.851^{*}$ & 0.606 & 0.538 & -0.088 & 1 & \\
Width $_{\text {crown }}(\mathrm{cm})$ & 0.278 & 0.283 & 0.246 & 0.210 & 0.070 & 0.264 & 1 \\
\hline
\end{tabular}

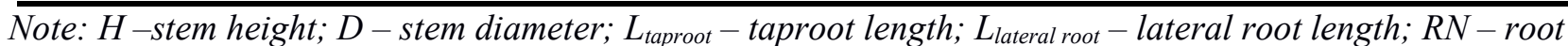

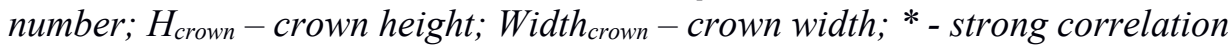

According to the Pearson's correlation table between the morphological parameters, stronger correlations were found between stem height and diameter $(\mathrm{p}=0.85)$, crown height and stem height $(\mathrm{p}=0.98)$ (Table 3$)$. We therefore found a positive correlation $(\mathrm{p}=0.64)$ between aboveground (stem height and diameter) and belowground (lateral and taproot) biomass parts. Moreover, the results of this study demonstrated that we should produce seedlings of Picea obovata both in greenhouse and open field conditions. It is well known that the success of reforestation and plantation establishment largely depends on the quality of seedlings.

\section{CONCLUSIONS}

Continuous forest degradation and deforestation in natural Picea obovata forests due to insufficient reforestation is becoming one of the pressing challenges in Mongolia. This study showed the results obtained from comparative study of seedling production
Although reforestation activities in Mongolia began in the 1970 s, there is still no evidence of reforestation in the natural Picea obovata forests. Unfortunately, at the national level, most of reforestation activities focus on restoration of natural Larix sibirica and Pinus sylvestris, less on Picea obovata. This may be due to the lack of planting materials and insufficient information on the state of natural Picea obovata forests and their reforestation need. To meet the existing need for seedlings that will be used for the reforestation of natural Picea obovata forests, it is recommended to opt for mass production of seedlings of Picea obovata in greenhouses.

methods in the forest-steppe zone. The experimental planting design included four different treatments of seedling production inside the greenhouses and in the open field, which differed in terms of watering norm, air humidity and temperature. 
Repeated measurements and sampling were carried out at the end of each growing season between 2018 and 2020. The results of the study greatly varied $(p<0.0001)$ among treatments due to their growing conditions.

We found that the seedlings had faster growth in height (52.4\%) and diameter $(62.3 \%)$, and greater biomass accumulation $(128.1 \%)$ in the greenhouse conditions than in the open field. A 3-year observation showed a greater proportion of stem bio-mass in the total biomass, and conversely, the dominant biomass proportion belonged to needles in open field treatments. It indicated that seedlings of spruce growing in open field release more biomass to photosynthesis to survive in the severe climate conditions.

The creation of stable conditions with high air relative humidity over 80\% (WN: 201

\section{REFERENCES}

1. Forest Fund of Mongolia (2020). Forest Research and Development Center. P. 25. (In Mongolian)

2. Bazarsad, Ch. (1988). Technology for seedling production of pine and larch seedlings in greenhouses // Scientific Journal of the Research Institute of Water, Meteorology and Forestry. №1, Ulaanbaatar, pp. 64-72. (In Mongolian)

3. Bat-Erdene, J. (2000). Results of a study on reforestation of Siberian larch and Scots pine forests in the burnt areas in the taiga belt. Extended abstract of the PhD thesis, Ulaanbaatar. P. 29. (In Mongolian)

4. Dashzeveg, Ts. (1990). Afforestation of Siberian larch forests in the logged forests of Central Khangai and Dornod Khentii, Mongolia. PhD thesis, Krasnoyarsk, OHU. Extended abstract of Ph.D. thesis, p. 36. (In Russian)

5. Dashzeveg, Ts. (2014). Scientific basis for coniferous forest restoration in Mongolia. Institute of Geoecology of the Mongolian Academy of Sciences. Ulaanbaatar. P. 42. (In Mongolian)

6. Chimeddorj, A. (1987). Contribution to the development of seedling production of Pinus sylvestris L. on sandy soils: Case study in Selenge day $^{-1}$ ), and internal temperature of $25^{\circ} \mathrm{C}$ (SR: $40 \%$ ) in the greenhouse had the most positive effect on the growth and biomass accumulation of the seedlings. We therefore conclude that to meet the existing needs for seedlings for the restoration of natural Picea obovata forests, seedling production in greenhouses should be recommended.

Acknowledgements: This work has been done within the framework of the project (P20203949) supported by the National University of Mongolia. The authors would like to acknowledge colleagues at the Forest Experimental Nursery of the Institute of Geography and Geoecology, MAS for providing human resources necessary for field data collection.

Aimag. Extended ab-stract of Ph.D. thesis. Ulaanbaatar, p. 28. (In Mongolian)

7. Dashzeveg, Ts., Amartuvshin. S. (2012). Results of a study on the plantation of Siberian pine and Siberian spruce seedlings. Proceedings of the Mongolian Academy of Sciences. Vol. 52 No 2 (202). (In Mongolian)

8. Odgerel, O. (1983). Consideration of the biological features for seedling production of Larix sibirica Ledeb. and Pinus sylvestris L. in the conditions of Selenge prov-ince, Mongolia. Extended abstract of Ph.D. thesis, p. 23. (In Mongolian)

9. Otgonbat, H. (1993). Development of technology for seedling production of Larix sibirica Ledeb. in the conditions of Central Khangai, Mongolia. Extended abstract of Ph.D. thesis, p. 23. (In Mongolian)

10. Enkhsaikhan, D. (1993). Development of seedling production technology willows in Mongolia. Ulaanbaatar. Extended abstract of Ph.D. thesis, p. 28. (In Mongolian)

11. Jalbaa, Kh. (1993). Development of seedling production technology Haloxylon ammodendron in the arid 
environments. Extended abstract of Ph.D. thesis, p. 28. (In Mongolian)

12. Haulenbek, A. (2000). Development of seedling production technology for Elaeagnus Moorcroftii in the conditions of Altai Uvur-Gobi. Extended abstract of Ph.D. thesis, p. 29. (In Mongolian)

13. Avirmed, A. (2000). Natural distribution of Populus diversifolia in Mongolia, and ways to restore them. Ulaanbaatar. Extended abstract of Ph.D. thesis, p. 26. (In Mongolian)

14. Tsogtbaatar, J. (1994). Structure and growth of Siberian larch forests in Western Mongolia. Sofia, Bulgaria. Extended abstract of Ph.D. thesis, p. 30.

15. Bothwell, K. S., Prescott, C. E., Jones, M. D. (2001). Factors contributing to the superior growth and $\mathrm{N}$ nutrition of 11-year-old lodgepole pine compared with Sitka spruce on a N-poor cedarhemlock cutover. Can J For Res., 31(7):1272-1279. doi:10.1139/cjfr-317-1272.

16. Grossnickle, S. C. (2005). Importance of root growth in overcoming planting stress. New Forests, 30(2-3):273-294. doi:10.1007/s11056-004-8303-2.

17. Heiskanen, J., Saksa, T., Luoranen, J. (2013). Soil preparation method affects outplanting success of Norway spruce container seedlings on till soils susceptible to frost heave. Silva Fennica, 47(1):1-17. doi:10.14214/sf.893.

18. Drössler. L., Agestam. E., Bielak. K., Dudzinska. M., Koricheva. J., Liziniewicz. M., Lof. M., Mason. B., Pretzsch. H., Valkonen. S. (2018). Over- and underyielding in time and space in experiments with mixed stands of Scots pine and Norway spruce. Forests. 9(8). doi:10.3390/f9080495.

19. Oscar, N., Karin, H., Urban. N., (2019). Early growth of planted Norway spruce and Scots pine after site preparation in Sweden. Scan J For Res., 34(8): 678688.

DOI:

10.1080/02827581.2019.1659398.

20. Langvall, O., Nilsson, U., Örlander, G., (2001). Frost damage to planted Norway spruce seedlings - influence of site preparation and seedling type. For Ecol Manag. 141(3):223-235. doi:10.1016/s0378-1127(00)00331-5.

21. Johansson, K., Hajek, J., Sjölin, O., Normark, E. (2015). Early performance of Pinus sylvestris and Picea abies - a comparison between seedling size, species, and geographic location of the planting site. Scand J For Res. 30(5):388-400.

doi:10.1080/02827581.2014.987808

22. Wallertz, K., Björklund, N., Hjelm, K., Petersson, M., Sundblad, L.G. (2018). Comparison of different site preparation techniques: quality of planting spots, seedling growth and pine weevil damage. New Forests, doi:10. 1007/s11056-018-9634-8.

23. Korotkov, I. A., Tsedendash, G. (1983). Forest map of Mongolia, Scale 1:1.500 000. GUGK USSR and MPR, Moscow.

24. Kasimov, N. S., Kosheleva, N. E., Sorokina, O. I., Bazha, S.N., Gunin, P. D., Enkh-Amgalan, S. (2011). Environmental-Geochemical State of Soils in Ulaanbaatar, Eurasian Soil Science, 7: 771-78.

25. Bazarsad, Ch. (1989). Effect of fertilization on the growth of Larix sibirica seed-lings // Special issue, Institute of Geography, MAS, pp. 2935. (In Mongolian) 